\title{
Rapid detection of Salmonella and country report
}

\author{
Jonathan T. Ou${ }^{1}$, Cheng-Hsun Chiu' ${ }^{1,2}$
}

\begin{abstract}
Abstrak
Puncak dari kejadian demam tifoid di Taiwan terjadi pada pertengahan kedua dari dasawarsa tahun 1930an, dengan jumlah kasus rata-rata sebanyak 1800 per tahun. Sejak waktu itu angka kejadian secara perlahan tetapi pasti, terus menurun, dan jumlah kasus pada saat ini berkisar antara 40-80 kasus per tahun, tanpa disertai adanya kematian kasus. Suatu penelitian retrospektifmengenai gambaran klinis pada kasus anak telah dilakukan pada 71 penderita anak-anak yang dikonfirmasi menderita demam tifoid dan dirawat di RS Chang Gung Memorial dari tahun 1982 hingga 1995. Sebagian besar kasus terjadi selama musim panas, dengan puncak pada bulan Juli. Dari seluruh 71 pasien tersebut, semuanya mempunyai gejala demam tinggi $\left(>38^{\circ} \mathrm{C}\right) ; 52 \%$ anak disertai dengan gejala sakit perut; $21 \%$ dengan keluhan mual/muntah; 35\% diare; $14 \%$ mengalami sembelit. Gambaran klinis lain yang ditemukan adalah hepatosplenomegali (56\%), nyeri perut (28\%), ruam kulit (11\%), ikterus (3\%), dan "gambaran toksik" (hanya satu). Jumlah sel darah putih adalah sekitar $10.000 \mathrm{sel} / \mathrm{mm}^{3}$ untuk usia $<4$ tahun dan 6,5-6,9x1000 sel/ $\mathrm{mm}^{3}$ pada anak dengan umur $5-15$ tahun. Komplikasi terjadi pada $25 \%$ penderita. Dari 16 isolat yang diperiksa untuk sensitifitas terhadap 7 jenis antibiotika, ternyata semuanya sensitif. Tidak seperti pada demam tifoid, salmonellosis non-tifoidal sering ditemukan di Taiwan. Telah dirancang suatu metoda PCR multipleks yang efektif, untuk usaha deteksi dini infeksi Salmonella. Dengan cara ini kadang-kadang, Salmonella hingga tingkat serovar, dapat didentifikasi dalam waktu sehari.
\end{abstract}

\begin{abstract}
The incidence of typhoid fever in Taiwan peaked in the latter half of 1930 s with an average of 1800 cases a year. Since then, with no apparent epidemics, it gradually but steadily decreased; and now, the incidence fluctuated between 40 and 80 cases a year with no death. Recently, a retrospective study was done on the clinical features of 71 pediatric patients who were confirmed to have typhoid fever and treated at Chang Gung Memorial Hospital between 1982 to 1995. Majority of the cases were found in the hot season with a peak in July. Of the 71 , all had a high fever $\left(>38^{\circ} \mathrm{C}\right) ; 52 \%$ abdominal pain; $21 \%$ nausea/vomitting; $35 \%$ diarrhea; and $14 \%$ constipation. Other clinical features seen were, hepatosplenomegaly (56\%), abdominal tenderness (28\%), skin rash (11\%), jaundice (3\%), and "toxic look" (only one). White blood cell counts were about $10^{4}$ cells $/ \mathrm{mm}^{3}$ for $<4$ years olds, and $6.5-6.9 \times 10^{3}$ cells $/ \mathrm{mm}^{3}$ for $5-15$ years olds. Complications were seen in 25\%. 16 strains were tested for their sensitivity to 7 antibiotics, and all were sensitive. Unlike typhoid fever, non-typhoid salmonellosis is rampant in Taiwan. To rapidly detect Salmonella infection, an effective multiplex PCR method was devised. In some cases, Salmonella at the serovar level can be identified with this method in a day.
\end{abstract}

\section{INTRODUCTION}

According to the Health Report ${ }^{1}$, for 31 years right up to the year of the Pacific War which started in 1941, the typhoid fever incidence in Taiwan had been maintained at an average of 1500 cases a year. A minor peak with an average of about 2000 cases a year was recorded for the last four years just before the War. After a blank of 3 years during the War when no record was kept, the incidence decreased to only about $20 \%$ of those recorded before. The incidence, since then, further decreased gradually but steadily, and in recent several years, the reported number of confirmed typhoid (including paratyphoid) fever per year fluctuated between 40-80 cases, where approxi-

\footnotetext{
${ }^{1}$ Laboratory of Bacterial Immunology, College of Medicine, Chang Gung University,

${ }^{2}$ Chang Gung Children's Hospital, Kweishan, Taoyuan, Taiwan
}

mately $20 \%$ were imported (brought in by foreign laborers). In contrast, non-typhoid salmonellosis is quite frequent and widespread: in just one major medical center in southern Taiwan, an average of 37 salmonellosis patients and more than 7 cases of bacterimia per month caused by salmonellae were registered in 1996.

Thus in Taiwan, typhoid fever occurs only sporadically, and consequently, in such situation, it is rather difficult to definitely diagnose typhoid fever, especially for pediatric patients. We thus undertook a retrospective study on the clinical features of 71 confirmed pediatric typhoid fever patients in the hope of finding useful specific clinical features that could be helpful for the diagnosis.

Many typhoid fever patients have diarrhea, which is often also caused by non-typhoid salmonellae, and a number of Salmonella strains readily cause a systemic infection such as bacteremia. Thus it is rather 
important not only to identify swiftly the etiologic Salmonella strain but also to distinguish it from Salmonella serovar typhi. We, therefore, devised an effective, sensitive and accurate diagnostic procedure for the identification of specific salmonella strains.

\section{MATERIALS AND METHODS}

\section{Patients, criteria of typhoid fever, and clinical data}

During the 14 years from 1982 to 1995,71 patients (45 boys and 26 girls) of 15 years old or younger were diagnosed to have typhoid fever and treated at the Chang Gung Memorial Hospital, Linkou, Taiwan. The diagnosis was made either by a positive culture of S.typhi from blood, bone marrow, feces or other body fluids or by Widal test, a serological method. The criterion of serologically positive typhoid fever was either ${ }^{1}$ a single $O$ titer of more than 1:320 without any other infectious source identified, or a fourfold rise in the $\mathrm{O}$ and/or $\mathrm{H}$ titer of paired sera in an interval of two weeks ${ }^{2}$. In all, 39 cases were diagnosed by blood culture, 3 by bone marrow culture, and 29 by Widal test. Demographic, clinical and laboratory data, were collected from the patient's charts. For statistical analysis, the $\chi^{2}$ test was used.

\section{Bacterial strain}

Both clinical isolates and laboratory strains, all maintained in this laboratory, were used. Altogether, 18 various bacterial species in addition to 23 Salmonella serovars were used to determine the sensitivity and specificity of the method ${ }^{2}$. These were: Shigella sonnei, Shigella flexneri, Citrobacter freuindii, Citrobacter diversus, Bacillus cereus, Enterobacter cloacae, Escherichia coli, Klebsiella pneumoniae, Proteus mirabilis, Pseudomonas aeruginosa, Pseudomonas putida, Aeromonas hydrophila, Serratia marcescens, Staphylococcus aureus, Staphylococcus epidermidis, Enterococcus faecalis, Enterococcus faecium, and Streptococcus pneumoniae; and the Salmonella serovars used were: Abortusovis, Agona, Anatum, Blockley, Choleraesuis, Clackamas, Derby, Dublin, Enteritidis, Gallinarum-Pullorum, Infantis, Kaapstad, Massenya, Muenchen, Newport, Panama, Schwarzengrund, Sendai, Thompson, Typhi, Typhimurium, Virchow, and Weltevreden.

Strains were routinely grown in complex nutrient broth including Gram-negative (GN) enrichment broth (Difco), and the plates used were xylose-lysinesodium agar, Salmonella-Shigella agar, and Campy- lobacter agar (all from Difco). Identification of Salmonella strains was carried out by the biochemical test as well as the serologic test for $\mathrm{O}$-and $\mathrm{H}$-antigen types. Salmonella serotypes were classified by the Kauffman-White scheme.

\section{PCR method}

A pair of primers used to amplify the $s p v C$ gene with PCR were prepared according to the sequence of basepairs (bp) 505 to 528 and 1052 to 10573,4 , respectively; and another pair for the amplification of the invA gene were prepared based on the sequence of bp 104 to 127 and 324 to 347 , respectively5. To prepare the samples for PCR assay, faecal samples were diluted $10-20$ fold to remove or minimize the effect of inhibitory compounds, incubated for $6 \mathrm{hr}$ at $37^{\circ} \mathrm{C}$ and used as the template for PCR. The blood samples were centrifuged at $1500 \mathrm{rpm}$, the buffy coat fraction was collected, its DNA was extracted and used in PCR. The PCR mixture contained $5 \mathrm{ml}$ of $10 \mathrm{x}$ PCR amplification buffer (supplied by Promega), $1.5 \mathrm{mM} \mathrm{MgCl}, 200 \mu \mathrm{M}$ each of the four deoxyribonucleoside triphosphates, $1 \mu \mathrm{l}$ each of primer pairs, $1.25 \mathrm{U}$ of Taq polymerase (Promega), $2 \mu \mathrm{l}$ of bacterial culture (or DNA derived from buffy coat fraction), and deionized $\mathrm{H}_{2} \mathrm{O}$ that was added to make up to a total volume of $50 \mu \mathrm{l}$. The amplification cycles were: denaturation for $30 \mathrm{~s}$ at $94^{\circ} \mathrm{C}$, annealing of primers for $30 \mathrm{~s}$ at $56^{\circ} \mathrm{C}$, and primer extension for 2 min at $72^{\circ} \mathrm{C}$. Prior to the first cycle, the bacteria were lysed by heating at $94^{\circ} \mathrm{C}$ for $1 \mathrm{~min}$, and after the last cycle, the mixture was incubated for $10 \mathrm{~min}$ at $72^{\circ} \mathrm{C}$. The mixture was electrophoresed in $2 \%$ agarose gel. The DNA fragments were then stained with ethidium bromide, examined and photographed under UV illumination.

\section{RESULTS AND DISCUSSION}

\section{Epidemiology of typhoid fever}

When the seasonal distribution of the 71 cases was examined, the majority (86\%) occurred in the hot months of May to October, exhibiting a typical pattern of food poisoning occurrence. The peak was in the month of July with 15 , followed by August with 12 , and next by June and September with 10 each. Thus, Taiwan is a typical sporadic area of typhoid fever occurrence, where many clinical features differed from those of epidemic or endemic areas $6-9$ as shown below.

Among the 6 symptoms (fever/chill, abdominal pain, 
nausea/vomiting, diarrhea, constipation; arthralgia, and delirium) presented at the time of the visit, all $(100 \%)$ had fever/chill, $52 \%$ abdominal pain, $35 \%$ diarrhea, $21 \%$ nausea/vomiting, $14 \%$ constipation, $4 \%$ arthralgia, and $1 \%$ delirium. Both of the two infants in Group A ( $<1$ year old) had diarrhea. In the remaining age groups, in general, about $1 / 3$ had diarrhea. Most children (19/28 or $68 \%$ ) of Group C (5-9 years olds) complained of abdominal pain and in the other groups the complaint was heard in about $40 \%$. Group $\mathrm{C}$ also showed the most frequency $(32 \%)$ of nausea/vomiting symptom, followed by $16 \%(5 / 31)$ in Group D (10 15 years olds), then 10\% (1/10) in Group B (2 4 years olds), and none in the infant group. On constipation, Group $\mathrm{C}$ again, showed the most, with $25 \%$ and then Group D with $10 \%$.

Upon examination, the presenting signs observed were as follows. The most frequent sign seen was hepatosplenomegaly with $71 \%$ of Group C, $60 \%$ of Group B, 50\% (one of the two) of Group A, and 42\% of Group D. Jaundice was seen 1 each in Group B and D. Skin rash was seen in all groups with $100 \%$ in Group A, 20\% in Group B, 11\% in Group C, and 10\% in Group D. Abdominal tenderness was not observed in the infant group but seen in the other groups: $10 \%$ in Group B, and 32\% in both Group C and Group D, respectively. There was only one stiff-neck, seen in Group C. All laboratory data except white blood cell count (WBC) were similar among the four groups. The level $\left(\mathrm{x} 10^{3} / \mathrm{mm}^{3}\right)$ of WBC in Group A was 13.3 \pm 0.6 , in Group B $10.9 \pm 9.1$, in Group C $6.9 \pm 3.9$, and in Group D $6.5 \pm 4.1$. Complications were seen in 17 patients in which 1 was in Group $A$, none in Group B, and the remainder in Groups $C$ and $D$ $\left(\chi^{2}=4.69, \mathrm{P}=0.032\right)$. As to the drug sensitivity of the strains, 16 isolates were tested in vitro with 7 frequently used antibiotics (ampicillin, chloramphenicol, cefamandole, cefotaxime, ceftriaxon, ceftazidine, and moxalactam) and all were sensitive.

\section{Epidemiology of salmonellosis and rapid detec- tion method}

As shown above, only sporadic cases of typhoid fever were found in Taiwan in recent years. However, other salmonellosis seemed to be quite common. To see its occurence, therefore, the incidence of salmonellosis including typhoid fever diagnosed in 1996 at a Southern Taiwan hospital was examined. It was seen throughout the year but more frequently during the high temperature season which is the high season for food poisoning in Taiwan. Of these, $71 \%$ were caused by S.typhimurium. Bacteremia caused by Salmonella was rather frequent also, and more than half, 53\%, were due to S.choleraesuis. Last year in this hospital, there was one typhoid fever case which was confirmed only after the isolation and identification of the causal strain, S.typhi. It is, therefore, important to rapidly detect whether or not the etiologic agent is Salmonella and more specifically, whether it is S.typhi or not. We therefore, devised a PCR method ${ }^{2}$ that was described in Materials and Methods. This methods utilized the findings that all Salmonella, including S.typhi, carry an invasive gene (inv) whose nucleotide sequence is unique; and that some Salmonella carry an $s p v$ gene-containing virulence plasmid $^{4}$. Thus, this method was designed to detect these two genes simultaneously using at least two pairs of primers, a pair for $i n v$ and the other for $s p v C$, in PCR: if a fragment was produced, the strain should be a Salmonella, and if two fragments appeared, the strain must be a Salmonella containing an spv-type virulence plasmid. In addition to the use of multiplex primers as just described above, another feature of this method was a prior dilution and incubation of the sample (faeces or other body fluids). Dilution and incubation served two purposes: to eliminate the components that inhibit PCR and to increase the number of viable bacteria for PCR. In the test using the strains listed in Materials and Methods, this methods easily and specifically detected Salmonella and further, simultaneously distinguished those containing the virulence plasmids from those without. The sensitivity of this method was 20 bacteria per PCR sample $(20 \mu \mathrm{l})$.

This PCR method was then applied to the clinical samples. In this application, conventional culture and identification method was simultaneously used. From 57 patients, 40 were shown to be infected with Salmonella detected either by culture or the PCR methods: $24(60 \%)$ were positive in culture, and $38(95 \%)$ were positive with PCR. The remaining two that failed to show a positive PCR gave a positive culture. The possible reasons for the failure of PCR to detect Salmonella in these two were: (i) there might be unusually high concentration of inhibitory compounds that were not sufficiently reduced with the level of dilution used and (ii) a bacterial number was lower than the detection limit of this PCR. Since the detection limit of this PCR was 20 bacteria per $20 \mathrm{ml}$, possibility (i) was the likely reason for the failure here. Despite this failure, it is apparent that this multiplex method is very much superior to the culture method in efficiency and accuracy. Of the 17 patients who gave a negative result by either method, two were in- 
fected with Campylobacter jejuni, four with rotavirus, and the remaining 11 unknown.

\section{PCR with three pairs of primers}

Since the efficiency of the PCR assay in the diagnosis of Salmonella enteritis was excellent (about 95\%), in contrast to $60 \%$ by culture alone, and the PCR technique could detect certain Salmonella serotypes simultaneously, an attempt is now being made to specifically detect and identify S.typhi, the etiologic agent of typhoid fever still endemic in many parts of the world, by adding another pair of primers for PCR. This pair of primers were prepared according to the nucleotide sequence of the EcoB section of the viaB gene of Citrobacter freundii $10,(\mathrm{Ou}$, unpublished data). This sequence was homologous to the corresponding sequence in the viaB gene of S.typhil1. Thus, in this modified technique. there were three pairs of primers, one for the inv gene, one for the $s p v$ gene, and one for the Vi gene. This PCR should produce four possible results: (i) no fragments produced, indicating that no Salmonella was present; (ii) one fragment made, meaning that non-typhi non-spv-type Salmonella was present; (iii) two fragments appeared, indicating that the Salmonella is either typhi or an spv-type depending on the size of the fragment from which one could determine whether the fragment was derived from the $\mathrm{Vi}$ gene or the $s p v C$ gene; and (iv) three fragments detected, indicating that this Salmonella contained all three genes, inv, viaB, and spv. Result(iv) would suggest that the Salmonella was most likely to be a Dublin which contains the $s p v$-type virulence type plasmid and occassionally the Vi. Other than these four cases, if only the primers for the viaB gene produced a fragment, the strain was likely a Citrobacter freundii. The preliminary test indicated that the primer pair for the Vi gene readily produced a fragment from Citrobacter freundii, S.typhi and Vi+ S.dublin.

Some Salmonella infections, such as S.typhi and S.dublin infection, induce fewer diarrhea cases, the former only about 33\% and the latter rarely (Chiu and Ou, unpublished data), but these Salmonella readily cause systemic infection via bacteremia. It is therefore desirable to examine the blood for these strains and distinguish them. Accordingly, we are currently applying the PCR method for the detection of bacteremia caused by Salmonella. Preliminary results indicated that it could detect the presence of Salmonelia in a sample containing as low as 500 bacteria. The current technique is not sufficiently sensitive. At- tempts are currently being made to improve the sensitivity.

\section{Acknowledgment}

This work was supported in part by grants DOH87HR-606 from National Health Research Institute, Department of Health, and NSC87-2314-B-182-067(to JTO) and NSC87-2314-B182A-052(to CHC) form the National Research Council, the Executive Yuan, Taiwan, Republic of China.

\section{REFERENCES}

1. Health, Vital statistics. Department of Health, the Executive Yuan, Taiwan Republic of China.1996.

2. Chiu CH, Ou JT. Rapid identification of Salmonella serovars in feces by specific detection of virulence genes, invA and spvC, by an enrichment broth culture-multiplex PCR combination assay. J Clin Microbiol 1996; 34: 2612-22.

3. Gulig PA, Galdwell AL, Chiodo VA. Identification, genetic analysis and DNA sequence of a $7.8 \mathrm{~kb}$ virulence region of the Salmonella typhimurium virulence plasmid. Mol Microbiol 1992; 6: 1395-411.

4. Gulig PA, Danbara H, Guiney DG, Lax AJ, Norel F, Rhen M. Molecutar analysis of spv virulence genes of the Salmonella virulence plasmid. Mol Microbiol 1993; 6: 825-30.

5. Rahn K, De Grandis SA, Clarke RC, McEwen SA, Galan JE, Ginocchio C, Curtiss III R, Gyles CL. Amplification of an invA gene sequence of Salmonella typhimurium by polymerase chain reaction as a specific method of detection of Salmonella. Mol Cell Probes 1992; 6: 271-9.

6. Khuri-Bulos N. Enteric Fevers in Children. Cli Pedia 1981; 20(7): 448-52.

7. Klotz SA, Jorgensen JH, Buckwold FJ, Graven PC. Typhoid Fever: An epidemic with remarkably few clinical signs and symptoms. Arch Intern Med 1984; 144: 533-7.

8. Butler T, Islam A, Kabir I, Jones PK. Patterns of Morbidity and mortality in typhoid fever dependent on age and gender: Review of 552 hospitalized patients with diarrhea. Rev Infec Dis 1991; 13: 85-90.

9. Misra S, Diaz PS, Rowley AH. Characteristics of typhoid fever in children and adolescents in a major metropolitan area in the United States. Clin Infect Dis 1997; 24: 998-1000.

10. Ou JT, Baron LS, Rubin FA, Kopecko DJ. Specific insertion and deletion of insertion sequence 1-like DNA element causes the reversible expression of the virulence capsular antigen Vi of Citrobacter freundii in Escherichia coli. Proc Natl Acad Sci 1988; 85: 4402-5.

11. Hashimoto Y, Li N, Yokoyama H, Ezaki T. Complete nucleotide sequence and molecular characterization of ViaB region encoding Vi antigen in Salmonella typhi. J Bacteriol 1991; 175: 4456-65. 